Revue bibliographique pour le domaine irano-aryen

\title{
Rüdiger Schmitt. « Urartäische Einflüsse im achaimenidischen Iran, vor allem in den Königsinschriften »
}

\section{Astrid Nunn}

\section{(2) OpenEdition}

Journals

Édition électronique

URL : http://journals.openedition.org/abstractairanica/42620

DOI : 10.4000/abstractairanica.42620

ISBN : 1961-960X

ISSN : 1961-960X

Éditeur :

CNRS (UMR 7528 Mondes iraniens et indiens), Éditions de l'IFRI

\section{Référence électronique}

Astrid Nunn, « Rüdiger Schmitt. « Urartäische Einflüsse im achaimenidischen Iran, vor allem in den

Königsinschriften » », Abstracta Iranica [En ligne], Volume 37-38-39 | 2018, document 24, mis en ligne le 10 mars 2018, consulté le 28 septembre 2020. URL : http://journals.openedition.org/abstractairanica/ 42620 ; DOI : https://doi.org/10.4000/abstractairanica.42620

Ce document a été généré automatiquement le 28 septembre 2020.

Tous droits réservés 


\title{
Rüdiger Schmitt. « Urartäische Einflüsse im achaimenidischen Iran, vor allem in den Königsinschriften »
}

\author{
Astrid Nunn
}

\section{RÉFÉRENCE}

Rüdiger Schmitt. « Urartäische Einflüsse im achaimenidischen Iran, vor allem in den Königsinschriften », in M. Krebernik, H. Neumann (éds.), Babylonien und seine Nachbarn in neu- und spätbabylonischer Zeit. Wissenschaftliches Kolloquium aus Anlass des 75. Geburtstags von Joachim Oelsner, Jena, 2. und 3. März 2007, (AOAT 369), 2014, Münster, p. $195-218$

1 L'influence de l'Urartu sur la Perse achéménide se fait. Sentir par exemple dans les murs cyclopéens, la manière de construire terrasses et enceintes dans les rochers, dans l'architecture religieuse des temples-tours, dans l'emploi de dalles claires et sombres pour les sols et dans les tombes creusées dans le rocher. L'A. ajoute les inscriptions funéraires, dont la titulature royale, l'introduction au texte de l'inscription («Darius déclare » à Behistun), la filiation et le style de proclamation sont également d'origine urartéenne. Ceci montrerait que la "manière urartéenne" était donc encore une réalité concrète sous Darius et qu'elle doit remonter à Cyrus. 


\section{AUTEURS}

\section{ASTRID NUNN}

Université de Munich 